\title{
O mestre, a obra e o amigo:
}

\author{
para Zé Carlos Rodrigues
}

\section{The master, the work and the friend:}

\section{to José Carlos Rodrigues}

\section{Everardo Rocha}

Doutor em Antropologia Social pelo Museu Nacional (UFRJ) e professor titular do Programa de PósGraduação em Comunicação da PUC-Rio. Pontifícia Universidade Católica do Rio de Janeiro, Departamento de Comunicação, Rio de Janeiro (RJ), Brasil.

Iniciar um texto em homenagem ao professor José Carlos Rodrigues poderia ser a partir de qualquer uma das diversas possibilidades que, em nossos mais de quarenta anos de convivência, ele descortinou para mim, seja como amigo, colega de departamento, professor, coautor ou, principalmente, como importante referência bibliográfica em minha formação. Escolho, portanto, esta última, pois sua obra acadêmica e seu projeto intelectual foram essenciais para meu próprio trabalho, bem como para centenas de outros pesquisadores que puderam conhecer seus inspiradores estudos.

A trajetória de José Carlos Rodrigues - melhor ainda, o "Zé Carlos" ou o "Zé", como carinhosamente o chamamos - inicia de forma brilhante no mestrado de Antropologia Social do Museu Nacional com a dissertação In Odio Habere, de 1975, orientada pelo nosso querido Roberto DaMatta. Não demorou muito para esse texto se transformar no justamente famoso livro Tabu do corpo, que, ao longo dos anos, teve cerca de dez reedições, sendo tão citado hoje como o foi no lançamento ainda na década de 1970. Também sobre o corpo e temas conexos, publicou os livros $O$ corpo na história e Corpo e consumo, do qual tenho a honra de ser coautor. 
O doutorado de José Carlos foi realizado na Université Paris 7 e lá escreveu, em 1981, a tese Les representations sociales de la mort et l'Occident industriel. A tese, tal como a de mestrado, foi publicada no Brasil: com o título Tabu da morte, em 1983. Seu orientador no doutorado, Robert Jaulin, escreveu, entre outros, La paix blanche: introduction à l'ethnocide, importante livro sobre a questão do etnocídio. Com a orientação de Roberto DaMatta e Robert Jaulin, além da dupla influência dos contextos do Museu Nacional e de Paris 7 em sua formação, Zé Carlos ampliou, cada vez mais, seus estudos nos oferecendo uma coleção de livros que se tornaram sólidas referências para todos os estudantes interessados em um viés intelectual no qual prevalecem as questões relativas à centralidade do campo do simbólico na vida social.

Não por acaso, o impacto das obras de José Carlos foi extremamente significativo também na área da Comunicação, na qual sempre lecionou na graduação e na pós-graduação. Assim, em 1989, escreveu o livro Antropologia e comunicação: princípios radicais, texto que tive o privilégio de ler antes de ser publicado e que assumiu uma importância crucial na área da Comunicação, algo que já vinha em curva ascendente com seus textos anteriores. O livro, como ele próprio diz bem no início, realizava seu desejo de escrever um trabalho de introdução tanto à Antropologia quanto às temáticas centrais que permeiam o campo de estudos da Comunicação.

Quando de sua publicação, Zé Carlos me convidou para escrever um pequeno texto que seria a orelha do livro. É óbvio que foi uma honra aceitar. Na ocasião, escrevi sobre o livro observações que não tenho dúvida de que seriam idênticas àquelas que escreveria hoje. Peço licença para repetir aqui alguns trechos do que escrevi há mais de trinta anos, quando afirmei que o livro se tornaria um clássico, pois ocuparia o lugar daquelas "coisas às vezes muito simples e quase sempre modestas que, de repente quando se vê, ficaram como que fora do tempo e foram longe no pensamento. São coisas que reuniram, ultrapassaram, radicalizaram, preencheram. E assim, tornam-se coisas - textos, no caso - inapreensíveis pela medida dos modismos intelectuais, dos apelos do óbvio, dos usos do sucesso ou das fragilidades do fácil. E isto apenas por que sua característica principal é a de ser medida de si mesmo e que vem ao mundo das ideias para trazer o novo, para espantar a sonolência, para sensibilizar o debate".

Esse livro de Zé Carlos, na minha experiência acadêmica particularmente, é da máxima importância, e penso que deveria ser leitura obrigatória para estudantes de Comunicação. Como indiquei na época, 
trata-se de um livro que "cumpre um destino rico e curioso de ser uma introdução à Antropologia que leva até às últimas (radicais) consequências a tarefa de ser e fazer Antropologia. Diferentemente dos manuais tradicionais de 'introdução' aqui se cria um percurso original (...) o que aqui encontramos neste trabalho de José Carlos Rodrigues é vida! Vida e vida nova que é soprada em direção a alguns temas cruciais dos estudos antropológicos (...) as noções de 'humanidade', 'cultura' e 'ideologia' são revisitadas. Mais que isto; são reinventadas com criatividade, rigor e inteligência". Como não poderia deixar de ser, o impacto do livro foi tal que ele se tornou um dos mais lidos, adotados e citados também nos cursos de Comunicação em todo o Brasil.

$\mathrm{Na}$ mesma linha, que aponta na direção dos complexos processos envolvidos na interdisciplinaridade, Zé Carlos escreveu, mais recentemente, em 2006, o livro Comunicação e significado: escritos indisciplinares, no qual pensa o conhecimento contemporâneo com disciplinas que não se fixam dentro de limites, espaços de poder e territórios específicos e que, nesse sentido, possam ser criativamente "indisciplinadas". Também podemos agregar aí os livros que reúnem seus ensaios, tais como Imaginários e dramas sociais: estudos de significação, de 2015, ou Ensaios em antropologia do poder, de 1992.

Mas não é só. Zé Carlos escreveu, seja em livros como Higiene e ilusão, seja em diversas de suas publicações, sobre temas como saúde, lixo, higiene, publicidade, infância, Big Brother, futebol e outros que tais. Sua obra acadêmica é multifacetada, criativa, sólida. Terá repercussão nos trabalhos de muitas gerações de estudantes e pesquisadores. E ainda mais: Zé Carlos é um professor inigualável, seja para turmas de 60 ou 70 alunos, como por vezes aconteceu nos cursos de graduação, seja para um grupo de seis ou sete alunos nos cursos de doutorado. Suas aulas são sempre cuidadosamente preparadas, bemhumoradas, interessantes e capazes de fazer os alunos refletirem sobre questões complexas. Uma vez me contou um acontecimento de sala de aula impagável e, para mim, revelador da sutileza do estilo Zé Carlos de ser. O evento, tal como ele mesmo acabou narrando no ensaio Esdrúxulos indivíduos, era uma aula na qual ele e seus alunos especulavam sobre a questão da origem da capacidade humana de falar, quando um deles afirmou: "Mas, professor, um dia, não interessa quando, um indivíduo deve ter sido o primeiro a falar". Zé Carlos, com sua tranquilidade usual, respondeu simplesmente: "O primeiro a falar com quem?" ... Entre as salas de aula lotadas e as refinadas orientações de doutorado, Zé Carlos é pura competência. 
Professor cativante e orientador dedicado, capaz de dar os rumos desejados para a tese, e que sempre teve como distinção o acolhimento das diferenças.

Do amigo Zé, meu colega de décadas no Departamento de Comunicação da PUC-Rio, marcam minha memória os incontáveis jantares, as lições que dele recebi sobre como dar aula em meu início de carreira, as dezenas de livros que me deu quando partia para alguns anos em Paris, sua participação na minha banca de mestrado e as muitas partidas assistidas no Maracanã com ele e nosso grande amigo comum Ronaldo Helal. Em certa ocasião, ao celebrarmos em uma churrascaria junto com o time do Flamengo a conquista de um título, inventamos a torcida "Fla-Ph.D." - coisa tão inusitada que rendeu até uma pequena nota em jornal. Assim, Zé Carlos e sua carreira docente, seu pensamento, seu coleguismo e amizade vão reverberar por muitas gerações nas aulas dos que foram seus alunos e na sua obra que ainda espera outros tantos grandes livros.

Everardo Rocha

ORCID: https://orcid.org/0000-0001-5821-1917 Pontifícia Universidade Católica do Rio de Janeiro, Departamento de Comunicação, Rio de Janeiro (RJ), Brasil. Doutor em Antropologia Social / UFRJ E-mail: everardo@puc-rio.br

Recebido em: 31 de agosto de 2021.

Aprovado em: 15 de setembro de 2021.

Este artigo é publicado em acesso aberto (Open Access) sob a licença Creative Commons Attribution Non-Commercial (CC-BY-NC 4.0), que permite que outros remixem, adaptem e criem a partir do seu trabalho para fins não comerciais, e embora os novos trabalhos tenham de lhe atribuir o devido crédito e não possam ser usados para fins comerciais, os usuários não têm de licenciar esses trabalhos derivados sob os mesmos termos. 